\title{
Zmora Internetu, czyli trolle meldują się na pokładzie. Hejterska solidarność na przykładzie internetowych forów plotkarskich
}

https://doi.org/10.15633/9788374389952.14

Nowe technologie mogą pogłębiać zrozumienie i ludzką solidarność. Internet to powszechnie dostępna sieć, niezwykle ważne narzędzie komunikacji społecznej, które odgrywa kluczową rolę w życiu człowieka. Dzięki mediom społecznościowym mamy możliwość utrzymywania kontaktu z osobami, z którymi dzieli nas np. duża odległość. Studentom i uczniom, Internet zapewnia niemalże natychmiastowy dostęp do dokumentów, książek czy prac naukowych, co było ogromnym ułatwieniem, szczególnie w czasie trwającej pandemii. Jednym z czynników mających wpływ na zjawisko solidarności jest z pewnością wspomniana komunikacja społeczna, która poprzez przedstawienie faktów i kształtowanie poglądów kieruje odbiorców na przyswajanie konkretnych wartości.

Solidarność jest niezwykle ważna dla społeczeństwa. Jowita Radzińska w swojej pracy pt. Solidarność: definicja i konteksty podkreśla, że to „jedyna tzw. wartość gorąca”, która „funkcjonuje w sferze publicznej i zazwyczaj nie wzbudza kontrowersji. Może odegrać istotną rolę w budowaniu społeczeństwa obywatelskiego, ponieważ wspiera postawy życzliwości, wzajemności i działania dla wspólnego dobra"1. Czy możemy natomiast mówić o wspólnym dobru w przypadku hejtu, gdy grupa internautów, która atakuje konkretną osobę, kieruje w jej stronę negatywne komentarze? Trzeba pamiętać, że idea solidarności może mieć również negatywny aspekt. Próbując zdefiniować ją najogólniej, możemy powiedzieć, że solidarność to relacja, oparta na empatii i budowaniu wspólnoty. W tym ostatnim niebagatelną role 
odgrywają media, które są kanałem dotarcia do drugiego człowieka. Papież Benedykt XVI powiedział, że muszą one „przezwyciężyć wszelką pokusę manipulacji, zwłaszcza w odniesieniu do ludzi młodych i stawiać sobie za cel formację i służbę. W ten sposób przyczynią się do ochrony, a nie do niszczenia tkanki społeczności obywatelskiej godnej człowieka”². Jednym z zadań środków komunikowania masowego jest zaangażowanie $\mathrm{w}$ formację $\mathrm{z}$ poszanowaniem zasad etyki ${ }^{3}$, z którą zjawisko hejtu stoi w jawnej sprzeczności. Niestety, mimo to, jest on powszechnym zjawiskiem w Internecie.

Hejt internetowy jest zjawiskiem opierającym się na oczernieniu, poniżeniu i postponowaniu kogoś lub czegoś. Może wystąpić wszędzie, gdzie istnieje możliwość komentowania treści internetowych i wyrażania opinii. Według Słownika języka polskiego jest to „obraźliwy i zwykle agresywny komentarz internetowy lub mówienie w sposób wrogi i agresywny na jakiś temat lub o jakiejś osobie"4.

W celu przybliżenia zjawiska hejtu w sieci, na potrzeby tego artykułu, przeprowadziłam krótkie, anonimowe badanie, w którym wzięło udział 300 osób. Na podstawie wyników ankiety, która została umieszczona w formularzu Google i udostępniona na kilku grupach, których działalność poświęcona jest celebrytom, można wyciągnąć następujące wnioski. 95\% osób korzystających $z$ Internetu padło ofiarą hejtera, a ponad 30\% respondentów przyznało się do obraźliwego komentowania innych ludzi czy wydarzeń. 60\% z nich śledzi internetowe fora plotkarskie, na których można wymieniać się spostrzeżeniami na temat wybranego celebryty/influencera. $30 \% \mathrm{z}$ nich zapewnia, że w dyskusji zazwyczaj bierze czynny udział. Ponadto fora i grupy internetowe poświęcone celebrytom stały się miejscem, które posłużyło zebraniu materiału empirycznego na potrzeby tejże pracy, dotyczącej zjawiska hejterskiej solidarności.

Internet stale się rozwija. Co za tym idzie, rozwija się również zjawisko hejtu, które cały czas ewoluuje i trudno je zatrzymać. Niepokojące może być to, że coraz częściej przenosi się ono z życia wirtualnego na realne. Zjawiskami pokrewnymi, związanymi z omawianym problemem, są tak zwane fake newsy, czyli wiadomości medialne, które opierają się na dezinformacji

2 Benedykt XVI, Środkiprzekazu: sieć komunikacji, jedności iwspótpracy. Orędzie na XL Dzień Środków Społecznego Przekazu, 2013.

3 M. Weresa, Zadania mediów w ujęciu Benedykta XVI. Na podstawie analizy zawartości orędzi na Światowy Dzień Środków Społecznego Przekazu (2006-2013), „Łódzkie Studia Teologiczne” 28 (2019) nr 1, s. 172-19o.

4 Hejt, w: Stownikjęzyka polskiego PWN [online], https://sjp.pwn.pl/szukaj/hejt.html(20.06.2021). 
i wcale nie muszą być kłamstwem. Mogą zawierać fragmenty prawdziwe, lecz przeinaczone lub wyrwane z kontekstu. Kanałami wykorzystywanymi do publikowania i rozpowszechniania w sieci fake newsów są rożnego rodzaju strony internetowe oraz media społecznościowe i sieciowe komunikatory ${ }^{5}$. Nieprawdziwa wiadomość, która została opublikowana w jednym $\mathrm{z}$ nich, może być łatwo rozpowszechniana w pozostałych. Istotną rolę odgrywają tutaj również wyszukiwarki internetowe. Kolportowanie niesprawdzonych informacji może prowadzić do manipulowania emocjami, co z kolei może być przyczyną narastania problemu z nieetycznymi wypowiedziami i zachowaniami.

Innym problemem i prawdziwą zmorą przestrzeni wirtualnej są trolle, czyli osoby, które swoimi kontrowersyjnymi lub napastliwymi wypowiedziami chcą sprowokować emocjonalne reakcje innych internautów. Są oni szczególnie widoczni w komentarzach pod postami związanymi z tematami politycznymi czy światopoglądowymi, np. na Facebooku. Największe zagrożenie niesie za sobą ta działalność trolli, która opiera się na nękaniu i przeprowadzaniu personalnych ataków w przestrzeni internetowej w celu ośmieszenia, zastraszenia lub zmuszenia zaatakowanej osoby do zrezygnowania z prowadzonych przez nią działań. Takim atakiem dotknięta została w ostatnim czasie youtuberka Julia Pelc, znana w sieci jako: Queen of the Black. Na swoim Tik-Toku podzieliła się z widzami zaskakującym nagraniem ze szpitala psychiatrycznego. Jak się okazuje, popularna nastolatka próbowała odebrać sobie życie, i to nie była jej pierwsza próba. Wszystko dlatego, ponieważ ktoś udostępnił w sieci jej nagie zdjęcia i rozpoczął ich rozpowszechnianie. Znaczna część internautów solidarnie twierdziła, że nastolatka zrobiła to tylko po to, by zyskać na popularności, ponieważ w kilka godzin przybyło jej kilkanaście tysięcy obserwujących ${ }^{6}$. W ostatnim czasie w mediach społecznościowych popularna była akcja \#Apostazjachallenge ${ }^{7}$. Jej twórcy okazywali wsparcie osobom, które z różnych przyczyn zdecydowały się odejść z Kościoła katolickiego. Zachęcali do tego innych pod pretekstem niezgody na to, by Kościół wyrażał swoje zdanie na tematy społeczno-polityczne.

5 A. Grycuk, Fake newsy, trolle, boty i cyborgi w mediach społecznościowych, „Analizy BAS” (2021) nr 1 (52).

6 Radiozet.pl, Julia Pelc chciała popetnić samobójstwo. Przedawkowata leki. „Nie mogę znieść hejtu”, https://www.radiozet.pl/Rozrywka/Plotki/Julia-Pelc-chciala-popelnic-samobojstwo-Queen-ofBlack-przedawkowala-leki (22.06.2021).

7 Theoniondaily.pl, Apostazja challenge, https://theoniondaily.com/apostazja-challenge/ (22.06.2021). 
O ile osoby chętne dokonać apostazji mogły liczyć na wsparcie w internetowej społeczności, o tyle osoby, które nagrywały filmiki ze świadectwami swojej wiary w ramach akcji \#JaraMnieWiara, otrzymywały masę nieprzychylnych komentarzy. Podobnym przykładem może być hejt na katolickim kanale youtubowym „Jednym Sercem”. W kolejnej części artykułu opisana zostanie jedna z plotkarskich grup jaką, była strona plotkarska Hydeapark Vogule Poland (grupa została zarchiwizowana 24 stycznia 2021 roku), której została poświęcona osobna cześć niniejszego artykułu. Strona ta przyczyniła się do tego, że na małżeństwo katolików prowadzących kanał „Jednym sercem” został przeprowadzony internetowy atak.

\section{Hydeapark Vogule Poland}

Vogule Poland to media (strona internetowa, kanał na Youtube, Instagram, Facebook) o zabarwieniu satyrycznym, poświęcone show-biznesowi i szeroko rozumianej rozrywce ${ }^{8}$. Zostały one założone przez parę homoseksualistów - Adama Mączyńskiego i Patryka Chilewicza. Twórcy sami o sobie mówią w następujący sposób: „Traktujemy świat z przymrużeniem oka, bo w naszym odczuciu inaczej się nie da" . Autorzy w cotygodniowej „prasówce" przekazują nowinki ze świata show-biznesu w często ironiczny i sarkastyczny sposób ${ }^{10}$. Niejednokrotnie też obnażali hipokryzję osób publicznych lub demaskowali obłudę celebrytów. Zdarza się, że gwiazdy, które poczuły się urażone ich dzielnością, blokują profile Vogule Poland. Do grona takich osób należy między innymi Edyta Górniak, która nie mogła poradzić sobie z komentarzami na swoim profilu, po tym, jak twórcy w swoich produkcjach zaczęli cytować jej słowa na temat pandemii i rzekomych statystów w szpitalach covidowych. Vogule Poland często zwraca także uwagę np. na sposoby promocji i ceny produktów reklamowanych przez influencerów, demaskując niewspółmierny koszt produktu do jakości, a także wytykając słabość formy przekazu. Przez takie działanie wizerunek influencera zostaje nadszarpnięty, a zaufanie do niego drastycznie spada. Największym „skandalem” związanym z Vogule Poland był ten, który wybuchł na ich zamkniętej grupie na Facebooku, w konsekwencji czego została ona zarchiwizowana.

8 Vogulepoland.net, O nas, online: https://www.vogulepoland.net/o-nas/ (22.06.2021).

9 Vogulepoland.net, O nas, online: https://www.vogulepoland.net/o-nas/ (22.06.2021).

10 Vogule Poland, Afera Zapiekankowa, https://www.youtube.com/watch?v=MCqNbDeomfI$\& \mathrm{t}=1661 \mathrm{~s}(22.06 .2021)$. 
Kontrowersyjna sytuacja dotyczyła Sylwestra Wardęgi, znanego polskiego youtubera ${ }^{11}$. Pewną ciekawostką może być fakt, że jeszcze przed nałożeniem na nią ograniczeń, poza fanami Vogule Poland, do wspomnianej grupy zaczęły dołączać osoby, które nie obserwowały jej twórców, a które prawdopodobnie pracowały dla portali plotkarskich. Założyciele wspomnianej strony w głównej mierze bazują na informacjach pojawiających się mediach społecznościowych gwiazd i celebrytów. Twórcy tego medium swój czas poświęcili głównie na śledzeniu tego rodzaju mediów, na czym bardzo zyskali. Widoczna była tendencja, w której przed pojawieniem się artykułu na jednym z portali plotkarskich (Pomponik, Pudelek, itp.) informacja od jakiegoś czasu widniała na Hydeaparku. Ponadto członkowie grupy również byli dobrze zorientowani w sprawach, które poruszali twórcy. Były tworzone np. specjalne posty, zwane nitkami, gdzie można było wspólnie komentować finałowy odcinek jakiegoś reality show czy finał programu artystycznego. Problemem grupy stała się jej liczebność. Przy liczbie 60 tys. członków było pewne, że administratorzy stracili nad nią kontrolę i nie radzą sobie z moderacją dyskusji. Użytkownicy grupy w komentarzach zaczęli nawzajem się hejtować. W skrócie skale tego zjawiska można było opisać wymownym „hejter hejtuje hejtera”. Niestety na grupie w pewnym momencie, być może nieświadomie, dano zielone światło do obrażania. Przykładem jest wspomniany wcześniej kanał „Jednym Sercem”. Małżeństwo, które go prowadzi, porusza temat wiary i nauki Kościoła katolickiego. Para w jednym ze swoich nagrań poruszyła temat współżycia małżeńskiego. Ich słowa zostały wyrwane z kontekstu. Film, choć został nagrany w sierpniu, w listopadzie - dzięki wspomnianej grupie - zyskał niezwykłą popularność. Artykuły o tym filmiku pojawiły się na wielu serwisach plotkarskich, jak i stronach poświęconych parentingowi (rodzicielstwu) ${ }^{12}$. Wydawałoby się, że jeśli danemu użytkownikowi content jakiegoś twórcy nie przypadł do gustu, to ten nie traci swojego czasu na oglądanie go, omija, blokuje, by nie wyświetlały mu się tego typu treści, a nie życzy drugiej osobie śmierci. Jednak przez działalność członków grupy Hydeapark Vogule Poland i rozpoczętej tam nagonki stało się dokładnie

11 Spidersweb.pl, Sylwester Wardęga: Vogule Poland to hipokryci. Vogule Poland: Tak, bywamy ijeszcze zamykamy nasza grupe na fejsie, https://spidersweb.pl/rozrywka/2021/01/25/vogule-polandvogulepolandisoverparty-wardega-plagiat (22.06.2021).

12 Mamotoja.pl, Youtuberzy: wspótżycie w matżeństwie jest OBOWIĄZKOWE. Odmowa prowadzi do grzechu i alkoholizmu, https://mamotoja.pl/wypowiedz-katolickich-youtuberow-mozemyodniesc-wrazenie-ze-wspolzycie-w-malzenstwie-jest-obowiazkowe-i-jest-to-prawda,aktualnosciartykul,30450,r1p1.html (23.06.2021). 
odwrotnie. Komentarze, które pojawiły się pod filmikiem, były bardzo wulgarne i krzywdzące. $Z$ czasem zostały przez twórców kanału usunięte, ale samo czytanie tysiąca wpisów z pewnością nie było miłym doświadczeniem. Zwłaszcza że pod adresem katolickich youtuberów padały zwroty typu „powinniście zdechnąć” albo „widać, że jesteś zastraszana przez męża, który jest gwałcicielem”. Twórców z kanału „Jednym sercem” z pewnością spotkała przemoc, której inspiracji trzeba szukać na wspomnianej grupie, gdzie wprost nagabywano do solidarnego hejtu i gdzie można było przeczytać zachętę do niego. $Z$ powodu tego rodzaju ekscesów powstała nowa grupa, już nie zrzeszająca fanów Vogule Poland, nazywa się CSI - Hydeapark i liczy ponad 40 tysięcy członków. Administratorzy panują nad tłumem, posty są selekcjonowane, a osoby, które łamią regulamin, bezpowrotnie blokowane i usuwane z grupy. Gdy wyciekły nagie zdjęcia jednej z popularnych polskich youtuberek, która obecnie nagrywa filmiki przeznaczone dla młodzieży, odpowiedzialni za grupę wydali oświadczenie, że nie będą promować ani robić sensacji z tej sytuacji, ponieważ wiedzą, że na dziewczynę wylała się już wystarczająca fala krytyki.

\section{Kafeteria}

To popularne forum dyskusyjne, na którym można dzielić się swoimi opiniami czy też radami na różne tematy. Stworzono ku temu specjalne zakładki, np. dom i rodzina, dieta i fitness, związki, rozrywka czy gwiazdy. W swojej pracy skupiłam się na tej ostatniej. Dyskusje dotyczące tego tematu oraz ich poziom sprawiają, że chęć jakiegokolwiek kontrolowania wymiany zdań musiałaby prowadzić do całkowitego zamknięcia tego działu.

W ramach prowadzonych badań starałam się zapoznać z najpopularniejszymi wątkami poruszanymi przez użytkowników. By można było wziąć udział w dyskusji, trzeba założyć konto oraz dołączyć do któregoś z istniejących już wątków albo stworzyć nowy. Kreatywność kafeterianek jest godna podziwu, ponieważ w nazwie nie mogą widnieć personalia znanej gwiazdy lub celebrytki, gdyż wtedy ów wątek zostanie usunięty. Co ciekawe, poza topowymi nazwiskami ze świata show-biznesu, pojawiają się również te nieco bardziej niszowe, np. instagramowych influencerek czy youtuberów, na których to opiera się ta praca. Ponieważ, jak już wspomniałam, w nazwie wątku nie mogą pojawić się personalia konkretnej osoby, użytkownicy portalu tworzą swoiste „kręgi zaufania”. Np. pewna youtuberka z Gdańska bardzo 
często pokazuje w swoich vlogach krem z pomidorów oraz przypomina widzom o tym, by w ciągu dnia znaleźli chwilę na odpoczynek. Stąd jeden z wątków nazywał się: „królowa passaty pomidorowej oraz relaksu”. Bardzo często avatarem użytkowników biorących udział w tego typu dyskusjach jest zdjęcie wybranego influencera/influencerki w bardzo niekorzystnej dla niego/niej pozie. Najczęściej jest to screen z jakiegoś filmiku, w którym wziął/ wzięła udział.

W dyskusjach na forum można zaobserwować wzajemną solidarność, polegającą na wyszukiwaniu przez użytkowników osób o takim samym, negatywnym nastawieniu do danego influencera bądź youtubera. Przejawia się to we wzajemnym, solidarnym "lajkowaniu” swoich komentarzy przez hejterów. O konstruktywnej krytyce nie ma mowy. Osoby próbujące napisać coś pozytywnego od razu są atakowane i w niewybrednych słowach proszone o opuszczenie wątku, przy czym atakujący swoje postępowanie usprawiedliwiają prawem do posiadania własnej opinii. Działalność kafeteryjnych trolli wykracza poza strefę Internetu i wchodzi w życie realne. Bardzo często zdarza się, że autorzy zjadliwych komentarzy ujawniają dane osobowe i adresowe, czyli tzw. dane wrażliwe, atakowanych osób. Tak było w przypadku vlogerki z Gdańska, Olsztyna oraz pewnej influencerki, która na co dzień promuje dietę wegańską i tworzy przepisowe e-booki. Takie postępowanie, choć wydaje się niedopuszczalne, świadczy o braku kontroli administratorów nad toczącymi się na portalu dyskusjami. Innymi przykładem podobnego typu zachowań jest swoiste szpiegostwo, które przejawia się w ujawnianiu danych finansowych, tematu pisanej pracy licencjackiej czy adresu marketu spożywczego, do którego dana osoba ma najbliżej.

Dochodzi także do przypadków nękania i pisania wiadomości do osób znajomych danego internetowego twórcy. Należy oczywiście zastrzec, że takie postępowanie nie jest na kafeterii standardem. Jednak po liczbie osób, u których takie zachowanie zaobserwowano, nie można go nazwać mniejszościowym. W obliczu przytoczonych faktów trudno zgodzić się na bagatelizowanie go i brak prewencji moderatorów czy administratorów strony.

\section{Podsumowanie}

Przemoc słowna była, jest i z całą pewnością będzie istniała nadal. Wraz z postępem technologicznym i zmianą wrażliwości społeczeństwa zmieniają się jej formy. Należy założyć, że fake newsy w dalszym ciągu będą 
rozpowszechniane w social mediach. Takie treści są bowiem atrakcyjne dla wielu osób. Istnieje dobrze funkcjonujący rynek usług zajmujących się manipulacjami w Internecie. Badania pokazują, że hejt jest zjawiskiem znanym i opisanym pod wieloma względami, jednak wiedza ta nie przekłada się na zmniejszanie występowania tego zjawiska. By przeciwdziałać hejtowi, technologia i wszelkie regulacje muszą być rozwijane i wprowadzane współmiernie do jego rozmiarów ${ }^{13}$. Jednym z tego typu ograniczeń może być utrudniony dostęp do zakładania fałszywych kont. $\mathrm{Z}$ tego, co ostatnio zaobserwowano, Instagram wprowadził możliwość blokowania użytkownika i blokowania kont, które użytkownik z tego samego IP utworzy. Usuwanie lub ukrywanie treści naruszających regulaminy oraz utrudnianie lub uniemożliwianie powtórnego ich publikowania w takiej samej lub zmodyfikowanych wersji byłoby realne, gdyby zatrudniono większą ilość moderatorów. Brak kontroli nad dużą grupą daje jawne przyzwolenie na hejterską działalność i solidaryzowanie się w niej użytkowników. Sektor technologiczny powinien stworzyć systemy wczesnego ostrzegania, które wykrywałyby zakazaną aktywność i po szybkiej analizie dokonywałyby oceny, a w ostateczności usuwały treści i blokowały konta. Do walki z hejtem przyłączył się także Kościół katolicki. Hejt znalazł się na liście grzechów w spisie grzechów uaktualnionych przez Penitencjarię Apostolską. Walka z hejtem to poniekąd walka z częścią ludzkiej natury ${ }^{14}$. Historia pokazuje, że solidarność powinna mieć wyłącznie pozytywny wydźwięk. Niestety w obecnych czasach, szczególnie gdy jest mowa o poglądach, zawęża pole do dialogu i niweluje miejsca na różnice zdania.

\section{Bibliografia}

\section{Literatura przedmiotu}

Benedykt XVI, Środki przekazu: sieć komunikacji, jedności i wspótpracy. Orędzie na XL Dzień Środków Społecznego Przekazu, 2013, https://opoka.org.pl/biblioteka/W/ WP/benedykt_xvi/przemowienia/media-or_24012006.html (10.08.2021).

13 A. Kukliński, Hejt w Internecie jako zagrożenie bezpieczeństwa człowieka, „Kultura Bezpieczeństwa. Nauka - Praktyka - Refleksje" (2018) nr 32, s. 131-146.

14 A. Kukliński, Hejt w Internecie jako zagrożenie bezpieczeństwa człowieka..., dz. cyt. 
Dobrzański D., Zasada solidarności. Studium z filozofii społecznej, Wydawnictwo Naukowe UAM, Poznań 2013.

Drożdż M., Etyka mediów w obronie wartości, WN UPJPII, Kraków 2019.

Goban-Klas T., Sienkiewicz P., Społeczeństwo informacyjne: Szanse, zagrożenia, wyzwania, Wydawnictwo Fundacji Postępu Telekomunikacji, Kraków 1999.

Grycuk A., Fake newsy, trolle, boty i cyborgi w mediach społecznościowych, „Analizy BAS” (2021) nr 1 (152).

Kamiński Ł., Nowe media w procesie ksztattowania tożsamości, Wydawnictwo Uniwersytetu Jagiellońskiego, Kraków 2018 .

Krajewska J., Etyczne dylematy u̇̇ytkowników portali i forów internetowych, „Przegląd Pedagogiczny" (2014) nr 1, s. 197-20o.

Kukliński A., Hejtw Internecie jako zagrożenie bezpieczeństwa człowieka, „Kultura Bezpieczeństwa. Nauka - Praktyka - Refleksje” (2018) nr 32, s. 131-146.

Radzińska J., Solidarność: definicja i konteksty, „Etyka” 48 (2014), s. 58-68.

Szulc M., Manipulowanie informacją w sieci za pomoca fake newsów jako zagrożenie dla młodzieży, „Psychologia Wychowawcza” (2020) nr 59 (17), s. 140-158.

Weresa M., Zadania mediów w ujęciu Benedykta XVI. Na podstawie analizy zawartości orędzi na Światowy Dzień Środków Społecznego Przekazu (2006-2013), „Łódzkie Studia Teologiczne" 28 (2019) nr 1, s. 172-19o.

Trzcińska J., Internet jako rewolucja, czyli wolność, równość $i$ solidarność $w$ XXI wieku, https://www.academia.edu/17413363/Internet_jako_rewolucja_czyli_wolno\%C5\%9B\%C 4\%87_r\%C3\%B3wno\%C5\%9B\%C4\% 87_i_solidarno\%C5\%9B\%C4\%87_w_XXI_wieku(10.08.2021).

\section{Literatura źródłowa}

RADIOZET, Julia Pelc chciała popetnić samobójstwo. Przedawkowata leki. „Nie moge znieść hejtu”, https://www.radiozet.pl/Rozrywka/Plotki/Julia-Pelc-chcialapopelnic-samobojstwo-Queen-of-Black-przedawkowala-leki (22.06.2021).

THEONIONDAILY, Apostazja challenge, https://theoniondaily.com/apostazja-challenge/ (22.06.2021).

VOGULEPOLAND, O nas, https://www.vogulepoland.net/o-nas/ (22.06.2021).

VOGULEPOLAND, Afera Zapiekankowa, https://www.youtube.com/watch?v=MCqNbDeomfI\&t=1661s (22.06.2021).

Stownik języka polskiego PWN, https://sjp.pwn.pl/szukaj/hejt.html (22.06.2021).

SPIDERSWEB, Sylwester Wardega: Vogule Poland to hipokryci. Vogule Poland: Tak, bywamy i jeszcze zamykamy nasza grupe na fejsie, https://spidersweb.pl/ 
rozrywka/2021/o1/25/vogule-poland-vogulepolandisoverparty-wardega-plagiat (22.06.2021).

\section{Abstrakt}

\section{Zmora Internetu, czyli trolle meldujq się na pokładzie. Hejterska solidarność na przykładzie internetowych forów plotkarskich}

Media społecznościowe pozwalają internautom na swobodne i anonimowe (w przekonaniu użytkowników) wyrażanie swoich myśli i opinii. Zalet nowych mediów jest dużo, jedną z najważniejszych jest podtrzymywanie więzi międzyludzkich i wpływanie na relację bez osobistego kontaktu (twarzą w twarz). Pogłębienie stosunków przejawia się także zwiększeniem ludzkiej solidarności. Mimo niewątpliwych zalet, media społecznościowe mają także swoje wady i mogą stanowić również poważne zagrożenie. Do tych ostatnich niewątpliwie należy problem mowy nienawiści, który w Internecie jest obecnie powszechnym zjawiskiem.

Dzięki swojej specyfice media społecznościowe w łatwy i dostępny sposób mogą przy-czynić się do grupowego hejtu czy obmowy zarówno pojedynczych osób (np. kolegi z klasy), jak i całych grup społecznych. Jedną z najbardziej narażonych na hejt grup są osoby publiczne, m.in. influencerzy, na których skupiam się w swoich badaniach. Sława influencera rzadko przekłada się na społeczną popularność i rozpoznawalność. Grono influencerskich odbiorców stanowi stosunkowo wąska grupa użytkowników. Choć odsetek osób chcących porozmawiać na temat danego influencera jest stosunkowo niewielki, to jednak „kompetencje” tych internautów mogą być porównywane z wiedzą i zaangażowaniem cechujących największych wielbicieli polskich i zagranicznych gwiazd. Środowisko influencerskich plotkarzy cechuje też niebywała solidarność, i to nie tylko jeśli chodzi o opinię na temat danego twórcy. Należy tutaj zaznaczyć, że w zdecydowanej większości przypadków rozmowy toczące się wokół influencerów na internetowych forach są zwykłym hejtem. Agresywna i nieuzasadniona krytyka osłabia wizerunek internetowego twórcy. Opublikowane na forach internetowych fake newsy na temat danego influencera, które momentalnie stają się tematami wiodącymi wśród zainteresowanych, bardzo łatwo jest rozpowszechnić w serwisach społecznościowych.

Celem artykułu jest przedstawienie powyższych zjawisk i roli, jaką odgrywają w tworzeniu i rozpowszechnianiu nieprawdziwych treści w mediach społecznościowych internetowe trolle, skupiające się w konkretnym miejscu - na forach 
plotkarskich. Ich solidarność bywa wręcz obsesyjna i niesie ze sobą zagrożenie bezpieczeństwa twórcy. Prezentacja zawiera również krótki przegląd sposobów i konsekwencji rozpowszechniania nieprawdziwych treści, a także najważniejsze działania niezbędne do walczenia z hejtem.

Słowa kluczowe

solidarność, hejt, fake newsy, media społecznościowe, trolle internetowe 
